\title{
Talking Stick sebagai Inovasi dalam Aktivitas Mengomunikasikan untuk Meningkatkan Pemahaman Siswa
}

\author{
A. A. G Agung1, *, IW Widiana 2,*, P. Indah Tresnayanti \\ 1 Jurusan Pendidikan Guru Sekolah Dasar, Universitas Pendidikan Ganesha \\ 2 Jurusan Pendidikan Guru Sekolah Dasar.Universitas Pendidikan Ganesha \\ 3 Jurusan Pendidikan Guru Sekolah Dasar.Universitas Pendidikan Ganesha
}

\begin{abstract}
Abstrak
Penelitian ini bertujuan untuk mengetahui pengaruh aktivitas mengomunikasikan dalam pendekatan saintifik berbantuan talking stick terhadap dimensi proses kognitif siswa kelas IV tahun pelajaran 2016/2017 di SD Kabupaten Buleleng. Penelitian ini merupakan penelitian eksperimen semu dengan populasi seluruh kelompok siswa kelas IV di SD rintisan kurikulum 2013 di Kabupaten buleleng. Populasi penelitian ini berjumlah 353 siswa. Sampel penelitian sebanyak dua kelas yang berjumlah 76 siswa. Data dikumpulkan dengan teknik tes serta dianalisis dengan teknik statistik deskriptif dan inferensial (uji t). Hasil penelitian ini menunjukkan bahwa terdapat perbedaan dimensi proses kognitif yang signifikan antara siswa yang dibelajarkan dengan aktivitas mengomunikasikan dalam pendekatan saintifik berbantuan talking stick dan siswa yang dibelajarkan dengan aktivitas pembelajaran konvensional $\left(\mathrm{t}_{\text {hitung }}\right.$ $=5,27>$ ttabel $=1,99$ ).
\end{abstract}

\author{
Keywords: \\ Aktivitas \\ Mengomunikasikan, \\ Pendekatan Saintifik, \\ Talking Stick, Dimensi \\ Proses Kognitif
}

\section{Pendahuluan}

Kualitas sumber daya manusia menentukan kemajuan kemajuan suatu bangsa. Penciptaan sumber daya manusia yang berkualitas didapatkan dengan menerapkan pendidikan yang bermutu. Pendidikan yang bermutu akan menjadikan siswa aktif, produtif dan inovatif dalam mengembangkan potensi dirinya sehingga memiliki kecerdasan spritual, kecerdasan emosional, kecerdasan intelektual serta keterampilan yang diperlukan siswa baik untuk dirinya sendiri maupun masyarakat sekitarnya.

Pendidikan yang bermutu dapat diwujudkan dengan suatu kurikulum yang memberikan pengalaman langsung pada siswa dalam mengembangkan seluruh potensi yang dimilikinya. Kurikulum merupakan salah satu unsur dalam dunia pendidikan yang memberikan kontribusi yang signifikan untuk mewujudkan berkembangnya kualitas potensi peserta didik. Untuk mewujudkan hal tersebut maka diterapkanlah Kurikulum 2013 yang memiliki karakteristik pembelajaran yang menekankan pada keseimbangan antara sikap spiritual dan sosial, pengetahuan, dan keterampilan siswa, serta dapat diterapkan dalam berbagai situasi di sekolah dan masyarakat (lampiran 1 Permendikbud 57 tahun 2014). Pembelajaran saat ini berdasarkan Kurikulum 2013 menuntut perubahan paradigma dari pembelajaran yang berpusat pada guru menjadi pembelajaran yang berpusat pada siswaGuru sebagai fasilitator, evaluator, dan motivator agar siswa dapat mengkonstruksi sendiri pengetahuan melalui berbagai aktivitas yang menuntut peran siswa aktif ( Asri, 2014).

Pembelajaran dalam Kurikulum 2013 menggunakan pendekatan saintifik. Kosasih (2014:2) mengemukan bahwa "pendekatan saintifik merupakan pendekatan yang dalam kegiatan belajarnya mengutamakan kreativitas dan temuan-temuan siswa, sehingga pengalaman belajar yang mereka terima bukanlah hasil dari hafalan atau ceramah guru". Dalam Permedikbud No. 81 A tahun 2013 tentang Implementasi Kurikulum dikemukakan bahwa "dalam pendekatan saintifik siswa dituntun untuk menggunakan lima pengalaman belajar yaitu mengamati, menanya, menalar, mengasosiasi, dan mengomunikasikan". Penerapan Pendekatan Saintifik berkaitan erat dengan pengusaan keterampilan mengkomunikasikan. Pada saat siswa menemukan suatu konsep dibutuhkan komunikasi sebagai alat untuk menyampaikan kepada orang lain ( Ambarsari, 2016). Proses pembelajaran pada kurikulum 2013 diterapkan melalui pembelajaran berbasis tematik integratif pada seluruh jenjang kelas (Antari,2016). Bantuan guru diperlukan dalam menggunakan lima pengalaman belajar tersebut. Akan tetapi bantuan guru tersebut harus semakin berkurang dengan semakin bertambah dewasanya siswa atau semakin 
tingginya kelas siswa. Selain itu kurikulum 2013 juga menekankan pada pembelajaran kontekstual. Artinya, guru tidak hanya memanfaatkan buku sebagai sumber belajar, tetapi juga memanfaatkan kondisi nyata di sekitar siswa ( Putra, 2016).

Pengalaman belajar yang diperoleh siswa, seluruhnya dituangkan dalam penugasan kompetensi, yang dalam penerapkan Kurikulum 2013 diperoleh tiga kompetensi yaitu sikap, pengetahuan dan keterampilan. Dari penerapan kurikulum 2013 ini, Pemerintah mengharapkan peningkatan kualitas aktivitas pembelajaran disekolah menjadi lebih bermakna bagi siswa sehingga meningkatkan hasil belajar. Namun, pada penerapannya, aktivitas dalam pendekatan saintifik yang diharapkan, tidak berjalan secara optimal. Sehingga tidak ada perbedaan dari aktivitas pembelajaran yang diterapkan dalam kurikulum sebelumnya.

Aktivitas pembelajaran adalah aktivitas atau kegiatan apa saja dari suatu individu yang dikelola dengan maksud untuk memperbaiki keterampilan, pengetahuan dan kompetensi. Terdapat dua kriteria penting yang perlu dipahami untuk membedakan antara aktivitas pembelajaran dengan berbagai bentuk aktivitas lainnya. Yaumi (2011) menjelaskan aktivitas pembelajaran harus dirancang dan dikelola dengan berbagai cara, termasuk yang dipersiapkan oleh peserta didik yang melibatkan usaha untuk mentrasfer informasi dalam pengertian yang seluas-luasnya (pesan, ide, pengetahuan dan strategi)

Kurangnya variasi dalam aktivitas pembelajaran dapat menyebabkan kurangnya motivasi siswa dalam mengikuti pembelajaran. Sehingga, belum tercapainya hasil belajar yang optimal. Hasil belajar terbagi dalam tiga ranah, yaitu ranah kognitif, afektif dan psikomotor. Untuk mengukur hasil belajar kognitif guru menggunakan Taksonomi Bloom revisi dalam mendesain tujuan pembelajaran, yang menurut Anderson (2010) taksonomi tersebut direpresentasikan dalam 2 dimensi yaitu dimensi pengetahuan dan dimensi proses kognitif. Dalam penelitian ini secara khusus diukur dimensi proses kognitif yang dilihat dari hasil belajar yang diperoleh siswa. Anderson dan Kratwohl (2010) menjelaskan proses kognitif adalah cara yang dipakai siswa secara aktif dalam proses mengkontruksi makna. Dalam proses kognitif, ada beberapa dimensi proses kognitif yaitu mengingat, memhami, mengaplikasikan, menganalisis, mengevaluasi dan mencipta”.

Berdasarkan data observasi awal yang telah dilakukan pada tanggal 05-08 Januari 2017 di tujuh sekolah yang merupakan sekolah rintisan Kurikulum 2013 diperoleh data seperti pada tabel 1.1 berikut.

Tabel 1.1 Hasil Tes Studi Pendahuluan.

\begin{tabular}{|c|c|c|c|}
\hline Nama Sekolah & Kelas & Jumlah Siswa & $\begin{array}{c}\text { Nilai Rata-rata } \\
\text { Siswa }\end{array}$ \\
\hline \multirow{2}{*}{ SD Laboraturium Undiksha } & IV A & 37 orang & 67,3 \\
\hline & IV B & 37 orang & 65,1 \\
\hline SDN 4 Banyuasri & IV & 36 orang & 66,2 \\
\hline \multirow{3}{*}{ SDN 3 Banjar Jawa } & IV A & 32 orang & 62,1 \\
\hline & IV B & 31 orang & 64,2 \\
\hline & IV C & 31 orang & 71,6 \\
\hline \multirow{2}{*}{ SDN 4 Kampung Baru } & IV A & 25 orang & 52,6 \\
\hline & IV B & 21 orang & 57,4 \\
\hline SDN 4 Kaliuntu & IV & 39 orang & 63,8 \\
\hline SDN 6 Pejarakan & IV & 25 orang & 48,8 \\
\hline SDN 1 Busungbiu & IV & 39 orang & 57,3 \\
\hline$\sum 7 \mathrm{SD}$ & & 353 orang & \\
\hline
\end{tabular}

(sumber : wali kelas IV di sekolah rintisan kurikulum 2013 di Kecamatan Buleleng)

Berdasarkan tes studi pendahuluan yang dilakukan pada observasi awal pada tanggal 5 - 8 Januari 2017 di tujuh sekolah yang merupakan sekolah rintisan Kurikulum 2013 diketahui bahwa hasil belajar siswa terbilang sedang. Hasil belajar siswa ini menandakan perkembangakn dimesni proses kognitif tidak maksimal. Adapun penyebabnya adalah pertama, kesiapan siswa dalam mengikuti pembelajaran. Bagi siswa yang tidak memahami penerapan pendekatan saintifk akan merasa kebingungan dengan apa yang mereka pelajari. Kedua, siswa tidak fokus dalam mengikuti pembelajaran, aktivitas pembelajaran yang tidak variatif menyebabkan siswa menjadi bosan. Ketiga, kurang optimalnya aktivitas pembelajaran yang harus dilakukan dengan menerapkan pendekatan saintifik. Ketidak siapan guru dalam menerapkan kurikulum 2013 dapat menyebabkan proses pembelajaran tidak berjalan dengan efektif. Keempat, 
pengadaan buku yang belum sepenuh maksimal menyebabkan materi yang diterima kurang optimal terlebih lagi jika sumber belajar yang diberikan hanya berasal dari satu buku.

Sebagai guru yang profesional, sudah menjadi suatu keseharusan memiliki pengetahuan yang lebih luas serta mampu menciptakan aktivitas pembelajaran yang dapat memotivasi siswa. Salah satunya aktivitas pembelajaran yang dapat memotivasi siswa adalah aktivitas pembelajaran berbantuan talking stick. Aktivitas pemebalajaran berbantuan talking stick adalah aktivitas pembelajaran yang mengadopsi inovasi dari model pembelajaran talking stick. Dalam penerapan aktivitasnya bantuan tongkat dijadikan sebagai jatah atau giliran untuk berpendapat atau menjawab pertanyaan dari guru setelah siswa mempelajari materi pelajaran.

Sesuai dengan pemaparan tersebut, aktivitas pembelajaran berbantuan talking stick menantang siswa untuk dengan cepat menguasai materi pembelajaran, memotivasi siswa untuk berpartisipasi aktif dan interaktif dalam memberikan masukan berdiskusi dan menjawab soal. Sehingga aktivitas pembelajaran dapat membuat siswa tertarik, tertantang dan memiliki rasa tanggung jawab untuk menemukan pengetahuannya sendiri terutama dalam mendalami materi yang diberikan guru. Pembelajaran menggunakan talking stick mendorong siswa untuk lebih percaya diri mengemukakan pendapatnya dan melatih siswa untuk menerima pendapat dari orang lain. Hal ini juga didukung oleh penelitian Santiasih (2016) yang menyatakan bahwa penerapan talking stick dalam pendekatan saintifik dapat meningkatkan penguasaan kompetensi pengetahuan IPS dan motivasi belajar siswa kelas IV SDN 9 Padangsambian Tahun Ajaran 2015/2016.

Dalam pembelajaran dengan pendekatan saintifik, inovasi aktivitas pembelajaran berbantuan talking stick akan diterapkan pada langkah mengomunikasikan. Tahap mengomunikasikan adalah tahap dimana siswa menyampaikan kembali pengetahuan yang telah diperoleh dai proses mengamati hingga mengasosiasikan yang dapat dilakukan dengan menuliskan ataupun mencerikan kembali secara lisan. Penerapan aktivtas pembelajaran berbantuan Talking Stick akan dapat menciptakan proses pembeljaran yang memotivasi siswa sehingga dimensi proses kognitif dapat terakomodasi secara optimal.

Penelitian ini menguji bagaimana pengaruh aktivitas mengomunikasikan dalam pendekatan saintifik berbantuan talking stick terhadap dimensi proses kognitif siswa kelas IV. Hasil penelitian ini dijadikan sebagai salah satu referensi untuk meberikan inovasi pada aktivitas pembelajaran siswa khususnya aktivitas mengomunikasikan sehigga ativitas yang dilaksanakan menjadi lebih menarik, memotivasi dan menyanangkan bagi siswa. Hasil penelitian ini juga memperlihatkan perkembangan dimensi proses kognitif siswa yang lebih mendominasi di kelas IV.

\section{Metode}

Penelitian ini berjenis penelitian eksperimen semu karena peneliti membagi kelompok tanpa membedakan satu dengan yang lainnya. desain penelitian yang digunakan adalah non equivalent post test control group design (Sugiono, 2009:79) dengan melibatkan satu kelompok eksperimen dan satu kelompok kontrol yang hanya diberikan post-test (tes akhir) pada kedua kelompok.

Penelitian ini dilaksanakan di SD rintisan kurikulum 2013 yang ada di Kabupaten Buleleng. Populasi dalam penelitian ini adalah seluruh kelompok siswa kelas IV di SD rintisan kurikulum 2013 Kabupaten Buleleng. Banyak siswa seluruhnya 353 orang yang tersebar dalam 7 Sekolah Dasar yaitu SD Laboratorium Undiksha, SD Negeri 4 Banyuasri, SD Negeri 3 Banjar Jawa, SD Negeri 4 Kampung Baru, SD Negeri 4 Kaliuntu, SD Negeri 6 Pejarakan, dan SD Negeri 1 Busungbiu. Total populasi berjumlah 535 yang terbagi menjadi 11 kelas. Dari 11 kelas yang ada dalam populasi dilakuan pengundian untuk diambil dua kelas yang dijadikan sampel penelitian. Berdasarkan hasil random sampling, diperoleh siswa kelas IV SD 1 Busungbiu yang berjumlah 39 orang dan siswa kelas IVB SD Laboratorium Undiksha yang berjumlah 37 orang. Setelah diperoleh 2 kelas sebagai sampel, dilakukan pengundian untuk menentukan kelas eksperimen dan kontrol, diperoleh siswa kela IV SD 1 Busungbiu sebagai kelas ekspeimen yang diberikan perlakuan dengan aktivitas mengomunikasikan dalam pendekatan saintifik berbantuan talking stick dan siswa kelas IVB SD Laboratorium Undiksha sebagai kelas kontrol.

Penelitian ini melibatkan dua variabel yaitu variabel terikat (dependent variable) dan variabel bebas (independt variable). Variabel terikat dalam penelitan ini adalah dimensi proses kognitif siswa yang dilihat dari hasil belajar siswa. Hasil belajar adalah nilai akhir yang diperoleh siswa selama mengikuti proses pembalajaran dalam jangka waktu tertetu. Dari hasil belajar yang diperoleh siswa dilihat perkembngakan dimensi proses kognitif siswa yang meliputi kategori mengingat, memehami, mengaplikasikan, mengalisis, mengevaluasi dan mencipta. 
Pengumpulan data menggunakan tes yaitu post-test dengan tes urian untuk mengukur dimensi proses kognitif siswa. Tes uraian berjumlah 17 butir soal. Validitas isi dilakukan oleh dua pakar. Tes hasil belajar juga dianalisis butir soalnya untuk melihat reliabilitas dan tingkat kesukaran dari tiap butir soal dari hasil uji tes coba.

Analisis reabilitas tes menyatakan bahwa reliabilitas tes berada pada kualifikasi tinggi $(0,82)$. Sedangkan analisis tingkat kesukaran tes berada pada kualifikasi sedang $(0,57)$. Data hasil belajar siswa diambil dengan memberikan Post-test pada siswa setelah selesai menerapkan aktivitas mengomunikasikan dalam pendekatan saintifik berbantuan talking stick dan yang tidak menerapkan aktivitas mengomunikasikan dalam pendekatan saintifik berbantuan talking stick. Hipotesis dalam penelitian ini dianlisis dengan menggunakan uji t. Namun untuk membrikan gambaran terhadap sebaran data penelitian ini menggunakan analisis deskriptif dengan kriteria rata-rata ideal dan standar deviasi ideal seperti pada Tabel 1.2 .

Tabel 1.2. Kriteria Rata-rata Ideal dan Standar Deviasi Ideal

\begin{tabular}{cc}
\hline Rentang Skor Real & Klasifikasi/Predikat \\
\hline $51,00 \leq X \leq 68,00$ & Sangat Tinggi \\
$39,67 \leq X \leq 51,00$ & Tinggi \\
$28,33 \leq X \leq 39,67$ & Sedang \\
$17,00 \leq X \leq 28,33$ & Rendah \\
$0,00 \leq X \leq 17,00$ & Sangat Rendah \\
\hline
\end{tabular}

\section{Hasil Dan Pembahasan}

Penelitian ini menemukan bahwa pada kelompok eksperimen hasil belajar siswa setelah dibelajarkan dengan aktivitas mengomunikasikan dalam pendekatan saintifik berbantuan talking stick sebanyak 51,29, siswa mendapat nilai dengan kategori tinggi dan sangat tinggi, 30,77 siswa mendapat nilai dengan kategori sedang, dan 17,95 siswa mendapat nilai rendah dan $0,00 \%$ sangat rendah. Hasil berbeda didapatkan pada kelompok control, yang mana pada kelompok control hasil belajar siswa setelah dibelajarkan dengan pembelajaran konvensional sebanyak 48,65 siswa mendapat nilai yang termasuk kategori tinggi dan sangat tinggi, 37,84 siswa yang termasuk kategori sedang, dan 13,52 siswa termasuk kategori rendah dan sangat rendah. Jadi secara deskriptif dapat dijelaskan bahwa, sebaran data dalam penelitian ini menunjukkan bahwa pada kelompok eksperimen data hasil belajar siswa cenderung berada pada kategori sedang ke atas, sedangkan pada kelompok kontrol cenderung berada pada sedang ke bawah. Lebih detail hasil post-test terdapat 39 orang siswa pada kelompok eksperimen dan terhadap 37 orang siswa kelompok kontrol ditunjukkan pada Tabel 1.3.

Tabel 1.3. Hasil post-test siswakelompok ekperimen dan control

\begin{tabular}{llll}
\hline Rentang Skor Real & $\begin{array}{l}\text { Kelompok } \\
\text { eksperimen }\end{array}$ & Kelompok control & Klasifikasi/Predikat \\
\hline $51,00 \leq$ X $\leq$ Mi 68,00 & $4(10,26 \%)$ & $3(8,11 \%)$ & Sangat Tinggi \\
$39,67 \leq$ X $\leq$ Mi 51,00 & $16(41,03 \%)$ & $15(40,54 \%)$ & Tinggi \\
$28,33 \leq \mathrm{X} \leq$ Mi 39, 67 & $12(30,77 \%)$ & $4(37,84 \% 0$ & Sedamg \\
$17,00 \leq$ X $\leq$ Mi 28,33 & $7(17,95 \%)$ & $3(8,11 \%)$ & Rendah \\
$0,00 \leq$ X $\leq$ Mi 17,00 & $0(0,00 \%)$ & $2(5,41 \%)$ & Sangat Rendah \\
\hline
\end{tabular}

Berdasarkan kriteria skala lima dan sesuai dengan hasil analisis data bahwa mean hasil belajar pada kelompok yang dibelajarkan dengan aktivitas mengomunikasikan dalam pendekatan saintifik berbantuan talking stick adalah 40,49 (berada pada kategori tinggi). Sebaliknya mean pada kelompok yang dibelajarkan dengan pembelajaran konvensional adalah 38,70 (berada pada kategori sedang). Hal itu berarti bahwa nilai rata-rata hasil belajar siswa kelompok eksperimen lebih tinggi dai pada nilai rata-rata hasi belajar siswa kelompok control. 
Tabel 1.4. Rerata dan Standar Deviasi Data Hasil Post-Test Kelompok Eksperimen dan Kontrol

\begin{tabular}{lllll}
\hline Variabel & \multicolumn{2}{l}{ Kelompok Eksperimen } & \multicolumn{2}{l}{ Kelompok Kontrol } \\
\hline Post-test & Rerata (mean) & Standar Deviasi & Rerata (mean) & Standar Deviasi \\
\cline { 2 - 5 } & 40,49 & 10,61 & 38,70 & 10,26 \\
\hline
\end{tabular}

Setelah diperoleh rerata hasil belajar sisw, kemudian dilakukan analisis taiap kategori dimensi proses kognitif dari 17 soal urain post test yang diberikan kepada siswa. Dimensi proses kognitif dilihat dari Taksonomi Bloom Revisi. Anderson dan Karthwohl (2010) menjelaskan dimensi proses kognitif siswa terdiri dari C1-C6 yaitu mengingat, memahami, mengaplikasikan, menganalisis, mengevaluasi da mencipta. Dari analisis per kateori dimensi proses kognitif dipeoleh persentase kategori memahami lebih tinggi dibandingkan dengan ketegori lainnya, yaitu 35,17\% untuk kelompok eksperimen dan 33,82\% untuk kelompok kontrol. Persentase pencapaian kategori dimensi proses kognitif siswa disajikan pada tabel 1.5 .

Tabel 1.5. Persentase pencapaian kategori dimensi proses kognitif siswa

\begin{tabular}{lll}
\hline $\begin{array}{l}\text { Kategori Dimensi } \\
\text { Proses Kognitif }\end{array}$ & Kelompok Eksperimen & Kelompok Kontrol \\
\hline Mengingat & $11,17 \%$ & $9,14 \%$ \\
Memahami & $35,17 \%$ & $33,82 \%$ \\
Mengaplikasikan & $2,46 \%$ & $2,50 \%$ \\
Menganalisis & $6,60 \%$ & $6,76 \%$ \\
Mengevaluasi & $4,25 \%$ & $2,86 \%$ \\
Mencipta & $3,10 \%$ & $1,83 \%$ \\
\hline
\end{tabular}

Sebelum dilakukan pengujian hipotesis dengan uji $\mathrm{t}$ independent terlebih dahulu dilakukan pengujian terhadap prasyarat yang perlukan terhadap sebaran data hasil penelitian. Uji asumsi meliputi dua hal, yaitu (1) uji normalitas distribusi data terhadap keseluruhan unit analisis, dan (2) uji homogenitas varians antar kelompok.

Uji normalitas data dilakukan pada keseluruhan unit analisis yaitu kelompok eksprimen dan kelompok kotrol. Analisis yang digunkan pada pengujian normalitas sebaran data adalah analisis ChiSquare yang dibantu program Mricrosoft Excel 2010 for Windows. Ketentuan normalitas data ditentukan dengan melihat tabel chi-kuadrat. Data berdistribusi normal jika nilai $X^{2}$ hitung lebih kecil dari nilai $X^{2}$ tabel dengan signifikansi 5\% dan derajat kebebasan $(\mathrm{db})=4$ adalah 9,488. Ringkasan hasil uji normalitas data pada kelompok eksperimen dan kelompok control pada tabel 1.6.

Tabel 1.6. Ringkasan Hasil Uji Normalitas Distribusi Data

\begin{tabular}{llll}
\hline Sampel Penelitan & $X^{2}$ hitung & $X^{2}$ tabel & Kesimpulan \\
\hline Kelompok Eksperimen & 2,37 & 9,488 & \multirow{2}{*}{$X^{2}{ }_{\text {hitung }}<X^{2}$ tabel } \\
Kelompok Kontrol & 0,93 & 9,488 & \\
\hline
\end{tabular}

Berdasarkan Tabel 6 dapat dijelaskan bahwa nilai $\mathcal{X}^{2}$ hitung menggunakan statistik Chi-Square lebih kecil $X^{2}$ tabel. Hal ini menunjukkan bahawa sebaran data pada kelompok eksperimen berdistribusi normal. Hasil yang hampir sama juga diperoleh pada data kelompok kontrol. Terungkap bahwa nilai $X^{2}$ hitung lebihkecil dari nilai $X^{2}$ tabel dengan menggunakan statistik Chi-Square. Hal ini menunjukkan bahwa sebaran data pada kelompok control juga berdistribusi normal.

Uji homogenitas varians dilakukan berdasarkan data hasil belajar tematik pada kelompok eksperimen dan kelompok control. Jumlah masing-masing unit analisis adalah 39 dan 37 orang siswa. Uji 
homogenitas varians antar kelompok menggunakan uji F. Data dinyatakan homogeny jika $F_{\text {hitung }}<F_{\text {tabel. }}$ Ringkasan hasil uji homogenitas varians kelompok disajikan dalam tabel 7.

Tabel 1.7. Ringkasan Hasil Uji Homogenitas Varians

\begin{tabular}{lllllll}
\hline Sampel Penelitian & Mean & SD & Varians & $F_{\text {hitung }}$ & $F_{\text {tabel }}$ & Kesimpulan \\
\hline Kelompok Eksperimen & 40,49 & 10,61 & 112,52 & \multirow{2}{*}{1,07} & \multirow{2}{*}{1,73} & \multirow{2}{*}{$F_{\text {hitung }}<F_{\text {tabel }}$} \\
Kelompok Kontrol & 38,70 & 10,27 & 105,33 & & & \\
\hline
\end{tabular}

Berdasarkan Tabel 7 ringkasan hasil uji homogenitas varians untuk kelompok eksperimen dan kelompok control menunjukkan bahwa $\mathrm{F}_{\text {hitung }}<\mathrm{F}_{\text {tabel }}$ yang dibantu dengan program Mricrosoft Excel 2010 for Windows. Ini berarti bahwa varians antara kelompok siswa homogeny. Hipotesis penelitian yang diuji adalah terdapat perbedaan dimensi proses kognitif antara siswa yang dibelajarkan dengan aktivitas mengomunikasikan dalam pendekatan saintifik berbantuan talking stick dengan siswa yang tidak dibelajarkan dengan aktivitas mengomunikasikan dalam pendekatan saintifik berbantuan talking stick pada siswa kelas IV tahun pelajaran 2016/2017 di SD Kabupaten Buleleng. Uji hipotesis ini menggunakan uji-t independent "sampel tidak berkorelasi". Telah disampaikan bahwa varians kelompok eksperimen dan kelompok kontrol adalah homogen. Maka pada uji-t sampel tak berkorelasi ini digunakan rumus $u j i-t$ polled varians. Adapun hasil analisis untuk uji-t dapat disajikan pada Tabel 1.8.

Tabel 1.8. Ringkasan Data Hasil Uji Hipotesis

\begin{tabular}{lllllll}
\hline Kelompok & Varians & $\mathrm{N}$ & $\mathrm{db}$ & $\mathrm{t}_{\text {hitung }}$ & $\mathrm{t}_{\text {tabel }}$ & Kesimpulan \\
\hline Kelompok Eksperimen & 112,52 & 39 & \multirow{2}{*}{74} & \multirow{2}{*}{5,71} & \multirow{2}{*}{1,99} & $\mathrm{t}_{\text {tabel }}>$ thitung \\
Kelompok control & 105,41 & 37 & & & & $\mathrm{H}_{\text {a diterima }}$ \\
\hline
\end{tabular}

Berdasarkan hipotesis penelitian yang telah diajukan pada kajian teori kriteria pengujian $\mathrm{H}_{0}$ ditolak jika $t_{\text {tabel }}>t_{\text {hitung }}$ dan $\mathrm{H}_{1}$ diterima, dengan taraf signifikansi $5 \%$ dan didukung oleh perbedaan skor rata-rata yang diperoleh antara kelompok eksperimen yaitu 40,49 yang berada pada kategori tinggi dan kelompok control yaitu 38,70 yang berada pada kategori sedang (cukup tinggi) maka hipotesis alternatif diterima. Ringkasan data hasil uji hipotesis menunjukkan hal yang sama $t_{\text {tabel }}>t_{\text {hitung }}$ sehingga $\mathrm{H}_{0}$ ditolak dan $\mathrm{H}_{1}$ diterima, Dengan demikian, dapat diinterpretasikan bahwa terdapat perbedaan dimensi proses kognitif antara siswa yang dibelajarkan dengan aktivitas mengomunikasikan dalam pendekatan saintifik berbantuan talking stick dengan siswa yang tidak dibelajarkan dengan aktivitas mengomunikasikan dalam pendekatan saintifik berbantuan talking stick pada siswa kelas IV tahun pelajaran 2016/2017 di SD Kabupaten Buleleng.

Temuan lain dalam penelitian ini adalah perbedaan persentase dalam kategori dimensi proses kognitif antara kelompok siswa yang dibelajar dengan aktivitas mengomunikasikan dalam pendekatan saintifk berbantuan talking stick dan siswa yang dibelajarkan dengan siswa yang tidak dibelajarkan dengan aktivitas mengomunikasikan dalam pendekatan saintifik berbantuan talking stick. Untuk kelompok yang dibelajarkan dengan aktivitas mengomunikasikan dalam pendekatan saintifik berbantuan talking stick persentase yang diperoleh 11,17\% untuk kategori mengingat, 35,17\% untuk kategori memahami, 2,46\% untuk kategori mengaplikasikan, 6,60\% untuk kategori menganalisis, 4,26\% untuk kategori mengevaluasi, 3,10\% untuk kategori mencipta dan untuk kelompok yang dibelajarkan dengan aktivitas pembelajaran konvensional persentase yang diperoleh 9,14\% untuk kategori mengingat, 33,82\% untuk kategori memahami, 2,50\% untuk kategori mengaplikasikan, 6,76\% untuk kategori menganalisis, 2,86\% untuk kategori mengevaluasi, 1,83\% untuk kategori mencipta.

Hasil temuan menunjukkan bahwa kategori pemahaman memiliki persentase yang lebih tinggi dari kategori lainnya, hal ini berarti untuk siswa kelas IV lebih dominan dalam menjawab soal yang termasuk ke dalam kategori memahami/pemahaman dibandingkan dengan kategori lain dalam dimensi proses kognitif. Pemahaman merupakan kemampuan memahami masalah, menginterprestasian dan menyatakan kembali dengan kata-kata sendiri (Retno, 2012, p.3).

Perbedaan persentase dalam kategori dimensi proses kognitif ini bisa disebabkan oleh beberapa 
faktor diantara, siswa kurang mengerti dengan soal yang diberikan, kesiapan siswa dalam menjawab soal. Hasil wawancara dengan siswa menyatakan bahwa faktor lain yang diduga juga memberikan pengaruh yaitu faktor sarana dan prasarana pembelajaran, motivasi belajar, percaya diri siswa, kondisi siswa, menajemen kelas, suasana lingkungan sekolah, teman sebaya, dan orang tua. Hal ini menguatkan teori yang menyatakan ada dua faktor mempengaruhi keberhasilan seseorang dalam belajar yaitu faktor internal yang meliputi faktor jasmaniah, psikologi, dan keaktifan siswa dalam masyarakat, serta faktor ekstern yang meliputi faktor keluarga, sekolah, masyarakat (Slameto,2003)

Peningkatan ini tidak terlepas dari aktivitas mengomunikasikan dalam pendekatan saintifik yang diberikan inovasi talking stick. Kurniasih $(2015$, p.82) yang menyatakan bahwa model talking stick dilakukan dengan bantuan tongkat, tongkat dijadikan sebagai jatah atau giliran untuk berpendapat atau menjawab pertanyaan dari guru setelah siswa mempelajari materi pelajaran. Melalui pelaksanaan langkah-langkah pada model talking stick dan dipadukan dengan aktivitas mengomunikasikan dari pendekatan saintifik, akan merangsang siswa untuk menghilangkan srasa takutnya serta menumbuhkan rasa percaya diri mereka dalam menyampaikan solusi terhadap suatu permasalahan.

Aktivitas pembelajaran dalam mpendekatan saintifik berbantuan talking stick memiliki langkah kegiatan dimana pada tahap mengomunikasikan dalam pendekatan saintifik siswa diberikan tongkat secara bergilir untuk menyampaikan pendapat atau jawaban secara percaya diri. Kegiatan ini dapat meningkatkan rasa kepercayaan diri siswa, aktif dalam pembelajaran sehingga dimensi proses kognitif yang dilihat dari hasil belajar siswa dapat berkembang secara optimal.

Hasil penelitian ini didukung oleh Pranyandari (2014), hasil penelitian menunjukkan bahwa model pembelajaran talking stick berbasis concept mapping berpengaruh terhadap hasil belajar IPA siswa kelas V Sekolah Dasar Gugus IV Kecamatan Kuta Utara Tahun Ajaran 2013/2014. Selanjutnya penelitian oleh Putri (2016) menunjukkan bahwa penerapan model talking stick berbasis pedekatan saintifik dapat meningkatkan penguasaan kompetensi pengetahuan IPA siswa kelas V SD N 2 Sumerta Tahun ajaran 2015/2016.

\section{Simpulan Dan Saran}

Berdasarkan hasil pengujian hipotesis dan pembahasan, dapat disimpulkan bahwa aktivitas mengomunikasikan dalam pendekatan saintifik berbantuan talking stick berpengaruh positif terhadap dimensi proses kognitif siswa kelas IV di SD Kabupaten Buleleng. Siswa yang diberikan aktivitas mengomunikasikan berbatuan talking sitick menunjukkan hasil belajar yang lebih tinggi dari pada aktivitas pembelajaran konvensional. Selain itu hasil belajar yang diperoleh siswa juga menunjukkan siswa lebih dominan menjawab soal kategori pemahaman dalam dimensi proses kognitif. Penelitian ini memberikan kontribusi yang positif dalam memberikan inovasi dalam aktivitas pembelajaran dalam pendekatan saintifik.

Disarankan bagi guru, untuk mampu mengembangkan inovasi pembelajaran dengan mereapkan aktivitas mengomunikasikan dalam pendekatan saintifik berbantuan talking stick agar nanti dapat diterapkan oleh guru dalam proses pembelajaran. Guru yang inovatif ialah guru yang mampu menciptakan suasana pembelajaran yang menyenangkan namun sesuai dengan tujuan dan materi yang disampaikan.

\section{Daftar Pustaka}

Ambarsari, Desi. 2016. Implementasi Pendekatan Saintifik Untuk Meningkatkan Keterampilan Mengkomunikasikan Dan Prestasi Belajar Ipa Siswa Kelas Iv Sd. Jurnal Pendidikan Guru Sekolah Dasar Edisi 12 Tahun ke-5.

Anderson dan Krathwohl. 2010. Kerangka Landasan Untuk Pembelajaran, Pengajaran, dan Asesmen.Yogyakarta: Pustaka Pelajar.

Antari, Ni Pt. Linda, I Ngh. Suadnyana, D.B.Kt Ngr. Semara Putra. 2016. Penerapan Talking Stick Dengan Pendekatan Saintifik Untuk Meningkatkan Keaktifan Dan Penguasaan Kompetensi Pengetahuan Ipa. e-Journal PGSD Universitas Pendidikan Ganesha Jurusan PGSD Vol: 4 No: 1 
Asri, I.G.A. Agung Sri. 2014. Pembelajaran Kooperatif Pola Tematik Berbasis Lesson Study Untuk Meningkatkan Hasil Belajar. Jurnal Pendidikan dan pengajaran, Vol 47, No 2-3 tersedia di https://ejournal.undiksha.ac.id/index.php/JPP/issue/view/343.

Kementerian Pendidikan Dan Kebudayaan.2012.Dokumen Kurikulum 2013.Jakarta:Kemendikbud.

Kurniasih,dan Sani.2014. Sukses Mengimplementasikan Kurikulum 2013 Memahami Berbagai Aspel Dalam Kurikulum 2013. Yogyakarta: Kata Pena.

Kosasih.2014. Strategi Belajar dan Pembelajaran Implementasi Kurikulum 2013. Bandung: Yrama Widya.

Kurniasih, dan Sani.2016. Ragam Pengembangan Model Pembelajaran Untuk Peningkatan Profesionalitas Guru. Yogyakarta: Kata Pena.

Lisdayanti, Ni Putu.2014. "Pengaruh Model Pembelajaran Kooperatif Talking Stick Berbantuan Media Gambar terhadap Hasil Belajar IPA Siswa Kelas V SD Gugus 4 Baturiti”.UNDIKSHA

Permendikbud Nomor 81A Tahun2013 tentang Implementasi Kurikulum,2013.Jakarta : Kemendikbud.

Putri,N.M.D.D.2016. "Penerapan Talking Stick Berbasis Pendekatan Saintifik Untuk Meningkatkan Pengetahuan IPA Siswa Kelas V SD".Singaraja. E-Journal PGSD Universitas Pendidikan Ganesha Jurusan PGSD Vol: 4 No: 1 Tahun: 2016

Pranyandari, Ni Made.2014. "Pengaruh Model Pembelajaran Talking Stick Berbasis Concept Mapping terhadap Hasil Belajar IPA Siswa Kelas V Sekolah Dasar Gugus IV Kuta Utara Tahun Ajaran 2013/2014". UNDIKSHA

Putra, I Gede Dharma dan Putu Nanci Riastini. 2016. Analisis Kesenjangan Perencanaan Dan Pelaksanaan Pembelajaran Kurikulum 2013 Di Sdn 4 Kampung Baru. Vol 49, No 1 tersedia di https://ejournal.undiksha.ac.id/index.php/JPP/issue/view/532.

Retno Utari.2012. Taksonomi Bloom: Apa dan bagaimana menggunakannya? Pusdiklat KNPK. Tersedia pada www.bppk.depkeu.go.id.

Rukmini, E.2008.Deskripsi Singkat Revisi Taksonomi Bloom. Journal Universitas Negeri Yogyakarta. Tersedia pada journal.uny.ac.id. (diakses tanggal 08 Februari 2017).

Sani, R. A.2015. Pembelajaran Saintifik Untuk Implementasi Kurikulum 2013. Jakarta: PT Bumi Aksara.

Santiasih,N.L.A.2016. "Penerapan Talking Stick Dalam Pendekatan Saintifik Untuk Meningkatkan Penguasaan Kompetensi Pengetahuan IPS dan Motivasi Belajar Siswa Kelas IV SDN 9 Padangsambian".Singaraja. e-Journal PGSD Universitas Pendidikan Ganesha Jurusan PGSD Vol: 4 No: 1 Tahun: 2016

Shoimin, A.2014. 68 Model Pembelajaran Inovatif dalam Kurikulum 2013. (R. KR, Ed.) (cetakan I). Yogyakarta: Ar-ruzz Media.

Slameto. 2003. Belajar dan Faktor-faktor yang Mempengaruhinya. Jakarta: PT Rineka Cipta Sugiyono. 2009. Metode Penelitian Kuantitatif, Kualitatif Dan R\&D (Cetakan 7). Bandung: Alfabeta.

Sukardi.2008.Metode Penelitian Pendidikan Kompetensi dan Praktiknya.Jakarta:PT Bumi Aksara.

Syaodih, E.1998. "Perkembangan Kognitif Anak Prasekolah. Diunduh Dari File". Tersedia pada Upi. edu/Direktori/FIP/JUR._PGT K/196510011998022/perk_kognitif_a Nak. Pdf, 1-14.

Yaumi, Muhammad.2011. Aktivitas Pembelajaran dan Teori Aktivitas. Tersedia pada https://www.scribd.com/doc/52173631/Aktivitas-Pembelajaran-Dan-Teori-Aktivitas di akses pada tanggal 20 Februari 2017. 